\title{
Evaluation of fungicides as seed tratment against coriander wilt disease caused by Fusarium oxysporum f.sp. corianderii
}

\author{
MUKESH KUMAR JAT*, R. R. AHIR AND GOPAL LAL KAKRALIYA
}

Department of Plant Pathology, College of Agriculture, S. K. N. Agricultural University, JOBNER (RAJASTHAN) INDIA

\section{ARITCLE INFO}

Received : 27.01 .2017

Revised : 10.03 .2017

Accepted : 15.03 .2017

\section{KEY WORDS :}

Wilt, Coriander,

F. oxysporum,

Fungicides
*Corresponding author: mksepat@gmail.com

\begin{abstract}
Among all the tested fungicides, complete inhibition of the fungal growth i.e. 100.00 per cent was recorded with Bavistin (carbendazim) at $200 \mathrm{ppm}$ and $500 \mathrm{ppm}$ the tested concentrations. The next best fungicides in order of fungal growth inhibition were Carbendazim + Mancozeb (companion), Topsin-M (thiophanate methyl), Vitavax (carboxin + thiram) and Benomyl (benlate) which inhibited the fungal growth by Carbendazim was found significantly superior at 200 and 500 ppm with (100\%) inhibition of mycelial growth followed by Companion and Topsin- $\mathrm{M}$ at $500 \mathrm{ppm}$ and with (100\%). Seed treatment with Bavistin (carbendazim) resulted in lowest wilt incidence $(10.39 \%)$ result showed that increase with seed yield $1011.15 \mathrm{~kg} / \mathrm{ha}$ was recorded in Carbendazim followed by companion that showed wilt incidence of 12.22 per cent. Both these fungicides were found to be statistically at par with each other. Next effective seed dresser were Topsin-M and Vitavax that showed wilt incidence of 14.33 and 21.55 per cent, respectively. These fungicides were found to be at par with best fungicides. Seed treatment with Benomy were found to be least effective which showed wilt incidence of 24.15 per cent and decrease with seed yield $617.90 \mathrm{~kg} / \mathrm{ha}$ was recorded both the years.

How to view point the article : Jat, Mukesh Kumar, Ahir, R.R. and Kakraliya, Gopal Lal (2017). Evaluation of fungicides as seed tratment against coriander wilt disease caused by Fusarium oxysporum f.sp. corianderii. Internat. J. Plant Protec., 10(1) : 92-95, DOI : 10.15740/HAS/IJPP/ 10.1/92-95.
\end{abstract}

